\title{
Database directories
}

by Jim Jacobs

Prepared for the 1986 IASSIST conference, Marina del Ray, Calif., May 22-24, 1986.

\section{Introduction}

The following is a highly selective list of directories of [American] ${ }^{1}$ machine-readable data files. Emphasis is on those directories which are most current, most complete, or are unique in some useful way. This list is current as of May 1986.

\section{DIRECTORIES OF ONLINE DATABASES}

Computer-Readable Databases: A Directory and Data Sourcebook. Edited by Martha E. Williams. Chicago: American Library Association, 1985. 2 volumes.

Describes over 2800 publicly available databases, most of which are available online. Gives rather detailed descriptions of each database. A subject index lists databases in 550 categories. This directory can also be searched, full-text, on Dialo€ (file 230). Volume one covers databases in science, technology, and medicine; volume two covers business, law; the humanities, and social sciences; multi-disciplinary databases are listed in both volumes.

Data Base Directory, 1984-85. White Plains, Ny: Knowledge Industry Publications, Inc.. 1984, in cooperation with the American Society for Information Science.

Identifies and describes machıne-rcadable database, both bibliographic and non-bibliographic, which are available for public access online in North America. Lists fewer databases (about 1700 versus more than 2700) than Directory of Online Databases or Computer Readable Databases. Well indexed by subject, producer and vendor. Also available for searching full-text on BRS (database label: KIPD).

Directors of Online Databases. Quarterly, cumulatve. Santa Monica, CA: Cuadra Associates, Inc.

Lists and describes macnine-readable databases available online to the public. The spring 1985 issue lists 2760 databases, only slighty fewer than Computer Readable Databases, which includes a few which are not available online. Publıshed quarterly and available online on Westlaw. Good subiect and other indexes.

\footnotetext{
'Editor's note
} 
Directory of Periodicals Online: Indexed, Abstracted, and Full Text. Washington, D.C.: Federal Document Retrieval, 1985-86. 3 volumes.

This directory is useful if you have the name of a particular periodical and you want to know if it is indexed or abstracted online, or available for full text searching online. Will cover 25,000 periodicals when all 3 volumes are published.

\section{SPECIALIZED DIRECTORIES}

APDU Membership Directory. Princeton, NJ: Association of Public Data Users. Annual.

Lists and provides profiles of members in this organization of data users, producers, and distributors. All members are organizations.

Catalog of Machine-Readable Records in the National Archives of the United States. Washington, DC: National Archives and Records Administration, 1977.

Describes holdings of machine-readable data in the National Archives. Arranged by the same record groups as the National Archives Guide. These files are not available online, but most can be purchased on tape. A new edition is due in 1986.

Data Acquisitions. Storrs, CT: Roper Public Opinion Research Center, 1983- (irregular).

The Roper Center is an archive of sample survey data from over seventy countries. Data Acquisitions lists and describes new surveys in the archive. Currently there are over $\overline{900}$ studies available through the center in machine readable form. A newsletter. Data Set News Roper, announces new acquisitions.

A Directorv of Computerized Data Files. National Technical Information Service. Washington, D.C.: Government Printing Office. (annual).

Lists and describes over 1000 federal databases which are for sale from NTIS on computer tape. This catalog does not indicate online availability although some files may be available through vendors. Indexed by subject and agency:

Directorv of Databases in the Social and Behavioral Sciences. Vivian S. Sessions, ed. New York. NY: Sciences Associates, 1974.

Although dated, this directory is unique and is still valuable for identifying organizations that collect data files, and the types of files they collect. Many entries are for local data centers collecting locally produced data. Some examples: "Historical Data on the Social Welfare Policies in Europe", (1850-1965), "Polish Immigration in the U.S." (1776- ), "Urban Transportation Study, Amarillo Texas", (1940- ). Few, if any, of the data files listed here are available online. 